Chirurgia (2021) 116: 480-483

No. 4, July - August

Copyright@ Celsius

http://dx.doi.org/10.21614/chirurgia.116.4.480

\title{
Portojejunostomy: A Salvage Technique for Extrahepatic Bile Ducts Surgery
}

\author{
Horea Bocșe ${ }^{1}$, Dana Bartoș ${ }^{1,2^{*}}$, Ioana lancu ${ }^{1,2}$, Sandu Brînzilă', Nadim Al Hajjar ${ }^{1,3}$, Cosmin Puia ${ }^{1,3}$, Cornel lancu', \\ Adrian Bartoș
}

${ }^{1}$ Prof. Dr. Octavian Fodor Regional Institute of Gastroenterology-Hepatology, Cluj-Napoca, Romania

2Department of Anatomy and Embryology, Iuliu Hațieganu University of Medicine and Pharmacy, Cluj-Napoca, Romania

${ }^{3}$ Department of Surgery, Iuliu Hațieganu University of Medicine and Pharmacy, Cluj-Napoca, Romania

${ }^{*}$ Corresponding author:

Dana Bartoș, MD

Prof. Dr. Octavian Fodor Regional

Institute of Gastroenterology-

Hepatology, Cluj-Napoca, Romania

E-mail: bartosdanamonica@gmail.com

\section{Rezumat \\ Portojejunostomia: o tehnică salvatoare în chirurgia căilor biliare extrahepatice}

Odată cu dezvoltarea chirurgiei laparoscopie, colecistectomia efectuată prin acest abord minim invaziv a devenit standardul de aur, aducând multe avantaje în ceea ce priveşte evoluția postoperatorie. $\mathrm{Cu}$ toate acestea, incidența leziunilor biliare complexe a cunoscut o creştere. Portojejunostomia a fost practicată pentru prima dată la pacienți pediatrici cu atrezie biliară şi a presupus anastomozarea unei anse jejunale excluse, în Y a la Roux, cu placa hilară, unde se deschid canaliculele biliare, în ideea de a reintroduce bila în circuitul digestiv. În cazurile de leziuni biliare complexe, când nu există alte opțiuni de reconstrucție a căilor biliare, portojejunostomia reprezintă o tehnică salvatoare şi la pacienții adulți.

Cuvinte cheie: colecistectomie, leziuni iatrogene, ducte biliare, portojejunostomie, derivații biliodigestive

\section{Abstract}

As laparoscopic surgery has evolved, open cholecystectomy has been replaced with a new minimally invasive approach which is considered nowadays the gold-standard technique. Laparoscopic cholecystectomy has brought multiple advantages in terms of 
outcomes; however, the incidence of complex biliary injuries has been noticed. The portojejunostomy was first performed for pediatric patients with biliary atresia, involving the attachment of a Roux-enY loop to the porta hepatis in order to restore the bilioenteric continuity. In complex cases, with no options of reconstruction after biliary lesions, this technique has become a salvage procedure in adult surgery.

Key words: cholecystectomy, iatrogenic lesions, biliary duct, portojejunostomy, biliodigestive derivation

\section{Introduction}

Laparoscopic cholecystectomy is one of the most common surgical procedures with more than 750,000 cases/ year in USA (1). The main advantages of this approach: lower rate of mortality and morbidity, shorter length of hospital stay, served as the main reason to introduce it as a gold-standard procedure, albeit a rise in complex biliary lesions has been noticed with an incidence of $0.3-0.7 \%$ (2). The morbidity in these cases is up to $43 \%$, while the mortality between $1.7-9 \%(3-4)$. Besides affecting the quality of life, the legal aspect has also become a burden (1).

During the past decades, a series of classifications have been proposed in order to cover all aspects of biliary lesions. Nowadays, Strasberg and ATOM classifications are the most frequently used although an international consensus has not yet been reached $(5,6)$.

Recognizing the complexity of a biliary lesion is the first step for the proper treatment. The aim of the therapeutic approach is to treat these cases in tertiary hospitals for better outcomes.

For A-D types of Strasberg lesions, minimally invasive treatment through drainage or sphincterotomy are the first choice; for type E lesions, hepaticojejunostomy with a Roux-en-Y loop is almost always necessary. In extreme cases where biliodigestive anastomosis is not feasible due to extensive and high biliary tract lesions, the only option for salvage remains the porto-jejunostomy as a curative procedure or a "bridging" solution until liver transplantation (7).

\section{Brief History}

Kasai operation was first performed in 1959, by Morio Kasai for the treatment of biliary atresia in pediatric patients. The procedure involves the attachment of a Roux-en-Y loop to the porta hepatis (8). This procedure served as a "bridging" solution until the liver transplant could be performed, in order to reduce the risk of hepatic failure and biliary cirrhosis with high mortality rates (jaundice was reduced in up to $50-60 \%$ of cases) (8).

During the next decades, a series of adjustment have been made, becoming a salvage procedure also in adult pathology (9).

\section{Anatomy \\ Hilar plate}

The hepatic hilar area is a complex anatomical region due to multiple vascular and biliary variations. It consists of 3 plates: hilar plate, umbilical plate, and cystic plate. It is bounded above by $\mathrm{S} 4 \mathrm{a}$, on the right by the Rouviere sulcus and the cystic plate and on the left it is continuous with the umbilical plate (10).

At this level, the vascular and biliary elements are surrounded by a sheath that is continuous with Glisson's capsule, intrahepatically (11).

Biliary ducts are represented by the right and the left hepatic ducts which form together the common hepatic duct. The right hepatic duct is associated with the highest percentage of anatomical variations. In up to $53-72 \%$ it is formed by a posterior segmental duct and an 
anterior segmental duct, joining the left hepatic duct in the hilar confluence. However, three other variations have commonly been noticed: the posterior segmental duct joins the left hepatic duct (9-27\%), the anterior segmental duct joins the hilar confluence (7$14 \%)$, and the anterior segmental duct joins the left hepatic duct $(6-9 \%)(10,12)$.

\section{Surgical Technique}

The procedure involves the attachment of a Roux-en-Y loop to the porta hepatis after a thorough dissection exposing the biliary elements. It is most often performed for proximal biliary lesions when there are several secondary biliary ducts present at the level of the hilar plate. A proper work-up in terms of diagnosis and surgical indication for biliodigestive reconstruction is essential for the outcome.

The ideal intraoperative solution is represented by the possibility to perform a Hepp-Couinaud anastomosis or a bihepaticojejunostomy (7).

In extreme cases, with extensive biliary lesions, when the reconstruction is not feasible due to high sectioning of the biliary tract, with more than 3-4 biliary canaliculi, a temporary solution by performing a portojejunostomy should be taken into consideration.

The dissection at the level of the hilar plate should be performed in a delicate manner, taking into consideration the risk of causing tissue damage, leading to fibrosis and biliary duct obstruction (13) (Fig. 1).

During this operative time, an important step is the dissection of the liver parenchyma between segments III and IV, which surround the round ligament. After assessing the possibility of performing a hepaticojejunostomy, the dissection is followed by the anastomosis between a Roux-en-Y jejunal loop and porta hepatis. The anastomosis can be performed with continuous or interrupted sutures, typically 4-0 absorbable material, suturing the liver parenchyma and the side of the jejunostomy (Fig. 2A-B).

The role of the subhepatic drainage tube is

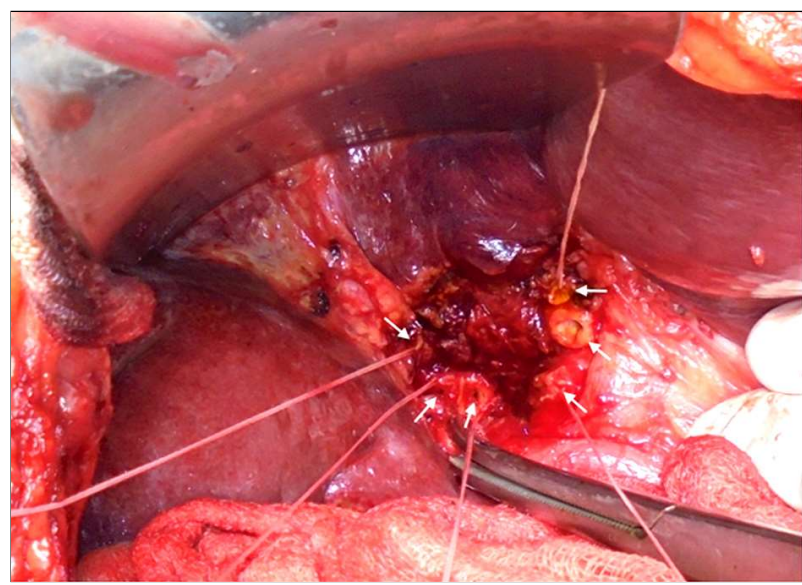

Figure 1. Porta hepatis after hilar plate dissection, with visualization of multiple biliary canaliculi (arrows), after a Strasberg E4 iatrogenic bile duct injury

(from personal files of the authors)
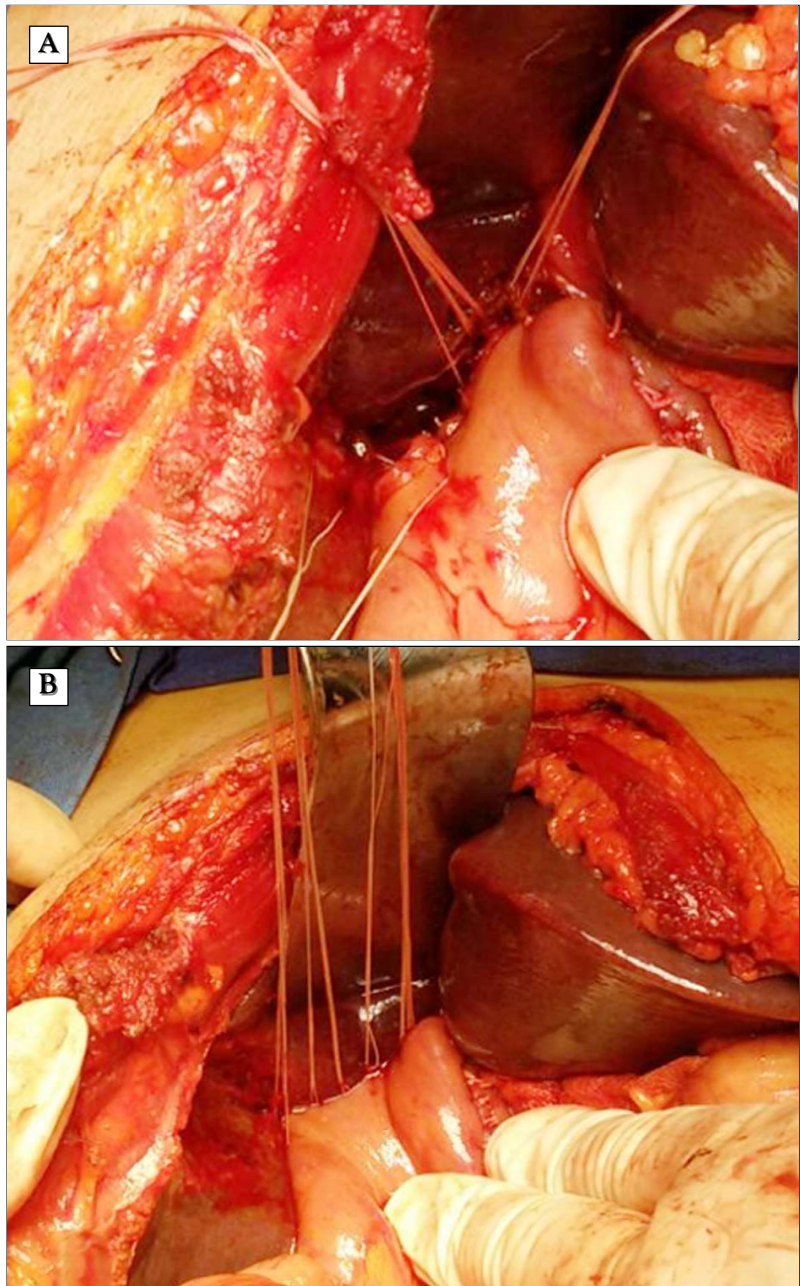

Figura 2. Portojejunostomy after a Strasberg E4 iatrogenic bile duct lesion. (from personal files of the authors).

(A) Sutures between portal plate and the jejunal loop.

(B) Final aspect of portojejunal anastomosis. 
of paramount importance in order to monitor complications such as anastomotic leakage. The risk of this complication is high due to the difference between the tissues: liver parenchyma-small bowel (14).

\section{Outcomes}

Portojejunostomy has proven to be an ideal procedure for children with biliary atresia in order to preserve the liver function as long as possible. Even though $80 \%$ of patients will ultimately need liver transplantation, up to $23 \%$ are alive 20 years later with the Kasai intervention (15).

In adult patients, case series that are published in literature suggest good outcomes in terms of survival and morbidity, although the main follow-up time is of 2 years (14).

Although anastomotic fistula is the main complication, in most cases it can be treated by conservative treatment $(9,14)$.

Between 2012-2020, our center performed 210 hepaticojejunostomies of which 7 portojejunostomies; in 4 cases the indications were iatrogenic lesions of biliary tract. For the other 3 patients, this technique was indicated after segmentary resection of the common bile duct. All patients presented postoperative bile leakage through the subhepatic drain. In all cases, the leakage stopped after postoperative ileus ceased (4-6 $6^{\text {th }}$ postoperative day), with no dehiscence of the portojejunostomy being recorded. To date, on long time surveillance, we had no specific complication or sequelae after these biliary reconstructions: stenosis, cholangitis, jaundice, perihepatic or hepatic abscesses.

\section{Conclusion}

This procedure represents a salvage technique for extreme cases of biliary lesions; therefore, every hepato-pancreato-biliary surgeon should be able to perform it.

Few data are published in literature, but the results suggest the importance of this procedure in complicated cases.

For the best outcomes, prevention, recognition, and surgical treatment in tertiary centers should be the steps for the management of complicated biliary lesions.

\section{Conflict of Interest}

The authors declare no conflicts of interests.

\section{References}

1. Archer SB, Brown DW, Smith CD, Branum GD, Hunter JG. Bile duct injury during laparoscopic cholecystectomy: results of a national survey. Ann Surg. 2001;234(4):549-558.

2. Pesce A, Palmucci S, La Greca G, Puleo S. latrogenic bile duct injury: impact and management challenges. Clin Exp Gastroenterol. 2019;12: 121-128.

3. Sicklick JK, Camp MS, Lillemoe KD, Melton GB, Yeo CJ, Campbell KA, et al. Surgical management of bile duct injuries sustained during laparoscopic cholecystectomy: perioperative results in 200 patients. Annals of surgery. 2005;241(5):786-92; discussion 93-5.

4. Dolan JP, Diggs BS, Sheppard BC, Hunter JG. Ten-year trend in the national volume of bile duct injuries requiring operative repair. Surgical endoscopy. 2005:19(7):967-73

5. Chun K. Recent classifications of the common bile duct injury. Korean J Hepatobiliary Pancreat Surg. 2014;18(3):69-72.

6. Fingerhut A, Dziri C, Garden OJ, Gouma D, Millat B, Neugebauer E, et al. ATOM, the all-inclusive, nominal EAES classification of bile duct injuries during cholecystectomy. Surg Endosc. 2013;27(12):4608-19.

7. Mercado MA, Domínguez I. Classification and management of bile duct injuries. World J Gastrointest Surg. 2011;3(4):43-8.

8. Garcia AV, Cowles RA, Kato T, Hardy MA. Morio Kasai: a remarkable impact beyond the Kasai procedure. J Pediatr Surg. 2012;47(5):1023-1027.

9. Pickleman J, Marsan R, Borge M. Portoenterostomy: an old treatment for a new disease. Arch Surg. 2000;135(7):811-7.

10. Kawarada Y, Das BC, Taoka H. Anatomy of the hepatic hilar area: the plate system. J Hepatobiliary Pancreat Surg. 2000;7(6):580-6.

11. Câmpeanu I. Left hepatic lobectomy. Chirurgia (Bucur). 2005;100(3):275-9. Romanian

12. Sarawagi R, Sundar S, Raghuvanshi S, Gupta SK, Jayaraman G. Common and Uncommon Anatomical Variants of Intrahepatic Bile Ducts in Magnetic Resonance Cholangiopancreatography and its Clinical Implication. Pol J Radiol. 2016;81:250-5.

13. Wildhaber BE. Biliary atresia: 50 years after the first Kasai. ISRN Surg. 2012;2012:132089

14. Gao JB, Bai LS, Hu ZJ, Wu JW, Chai XQ. Role of Kasai procedure in surgery of hilar bile duct strictures. World J Gastroenterol. 2011:17(37):4231-4234.

15. Lykavieris $P$, Chardot $C$, Sokhn M, Gauthier F, Valayer J, Bernard 0 . Outcome in adulthood of biliary atresia: a study of 63 patients who survived for over 20 years with their native liver. Hepatology. 2005;41(2):366-371. 